\title{
PREFERENTIAL CONSUMPTION OF LARGER FRUITS OF Piper arboreum (Piperaceae) BY Carollia perspicillata (Phyllostomidae) IN THE BRAZILIAN TROPICAL DRY FOREST
}

\author{
CONSUMO PREFERENCIAL DE FRUTOS MAIORES DE PIPER ARBOREUM \\ (PIPERACEAE) POR CAROLLIA PERSPICILLATA (PHYLLOSTOMIDAE) EM UMA \\ FLORESTA TROPICAL BRASILEIRA
}

\begin{abstract}
Luís Paulo PIRES ${ }^{1}$; Kleber DEL-CLARO ${ }^{2}$; Wilson UIEDA ${ }^{3}$
1. Msc., Universidade Federal de Uberlândia - UFU, Uberlândia, MG, Brasil; 2. Professor, Doctor, Universidade Federal de Uberlândia - UFU, Uberlândia, MG, Brasil. delclaro@ ufu.br; 3. Professor, Doctor, Universidade Estadual Paulista Júlio de Mesquita Filho, UNESP, Botucatu, SP, Brasil.
\end{abstract}

\begin{abstract}
Frugivorous animals may use morphological traits of food items such as size, hardness, shape, color and smell as cues that allow them to assess cost-benefit relationship of foraging activity. Fruit size is an important trait that influences feeding behavior of most frugivores, since there is a functional correlation between fruit size and frugivores' body size. Therefore, size-based preference is fundamental to understand plant-frugivore interactions and seed dispersal. In this sense, we tested the hypothesis of preferential consumption of larger fruits of Piper arboreum by the short-tailed fruit bat Carollia perspicillata in the Brazilian tropical dry forest. Results showed considerable variation in fruit size among and within plants. There was also significant difference in fruit ripening time among plants, which was not related to fruit size. Average size of remaining fruits reduced as they were removed from plants by the bats, which indicates preferential consumption of larger fruits. On the other hand, plant phenology constrained consumption of bigger fruits. Only a small fraction of plant crop was available for consumption each night, regardless of fruit size, which probably coerced bats to feed on smaller fruits as the availability of larger ones decreased. Results suggest that bat preference on fruit size is mediated by plant phenological strategies.
\end{abstract}

KEYWORDS: Fruit choice. Frugivory. Seed dispersal. Syndromes. Brazil.

\section{INTRODUCTION}

According to optimal foraging theory, animals should optimize energetic costs of foraging activities by reducing energy spent in searching, acquiring and processing food (PYKE, 1984). To be able to do this, foragers may use phenotypical traits of food items such as size, hardness, shape, color and smell as cues that allow them to assess costbenefit relationship of resources, which leads to differential consumption of these varying traits (GAUTIER-HION et al., 1985).

The 'syndrome hypothesis' states that seed dispersers choose fruits based on some particular traits (e.g. morphology, color, smell) and, thus, exert selective pressure on the evolution of fruit characteristics (JANSON, 1983; GAUTIER-HION et al., 1985). Despite the extensive literature on the influence of fruit traits on frugivores foraging behavior, there is considerable debate regarding the 'syndrome hypothesis' (CAMARGO et al. 2013). Fruit bearing plants and frugivores interaction networks are asymmetric and mainly generalistic (BASCOMPTE; JORDANO, 2007), and because of this low degree of specialization, most of fruit characteristics do not necessarily respond to directional selective pressure or constrain consumption by different frugivores (HERRERA, 2002, FLÖRCHINGER et al., 2010). For instance, a colorful fruit, which is a trait basically associated with visually oriented seed dispersers such as birds, may be consumed by smell-oriented animals as well. Therefore, frugivore choices that rely on fruit and plant traits remain an issue that requires further investigation (LOMÁSCOLO; SCHAEFER, 2010).

Among fruit traits, one that doubtlessly influences consumption is fruit size (JORDANO, 1995; FLÖRCHINGER et al., 2010). There is a functional correlation between frugivore's body mass and fruit size (FLEMING, 1991). For instance, plants bearing large and heavy fruits may limit their consumption by small-bodied animals, which usually do not have the necessary morphological and behavioral adaptations to remove, handle and consume them efficiently (WHEELWRIGHT, 1985). On the other hand, small fruits may not be energetically suitable for large-bodied frugivores, which need to spend more time foraging to achieve their energetic requirements, leading to increased energy expenditure and susceptibility to predation during foraging (MUSCARELLA; FLEMING, 2008). Thus, differential consumption of varying 
Preferential consumption...

fruit sizes by frugivores is an important feature to understand plant-frugivore interactions since it may affect seed dispersal and the fitness of both parties involved (HERRERA, 2002). Most studies have assessed frugivore size-based preference on fruits of different plant species (FUENTES, 1994; STANLEY et al., 2002, LOMÁSCOLO et al., 2010), but others have approached this selectivity on plant population and individual levels (JORDANO, 1995, MELLO et al., 2005, NUNES et al. 2007).

Fruit size may influence the foraging behavior of frugivorous bats (MUSCARELLA; FLEMING, 2008), but there is no specific pattern for these animals, since some species display a sizebased preference (KORINE; KALKO, 2005; NUNES et al., 2007), while others choose fruits irrespective of their size (DUMONT; IRVINE, 1998; WENDELN et al., 2000). According to optimal foraging theory (PYKE, 1984), it would be reasonable to assume that bats choose fruits in order to maximize their net energy intake and minimize risks by reducing exposure to predators such as owls and domestic cats, and so, foraging on bigger fruits may be the most profitable strategy because it would require fewer visits to the fruiting plant, whereas plants would benefit from enhanced seed dispersal per fruit removed. Here, we tested the hypothesis of preferential consumption of larger fruits of Piper arboreum Aubl. (Piperaceae) by the short-tailed fruit bat Carollia perspicillata (Linnaeus 1758) (Phyllostomidae).

\section{MATERIAL AND METHODS}

\section{Study site}

The study was conducted from August 2010 to August 2011 at Parque do Sabiá (hereafter PS), (48¹4'02" W, 18 54'52" S), in Uberlândia city, Brazil. The PS has ca. 35-ha and is mainly composed of a semideciduous forest, but it also includes some Brazilian Cerrado formations (GUILHERME et al., 1998).

\section{Species description}

Piper arboreum is a common understory tree species in gallery forests from Southeastern Brazil, and its fruits are consumed mainly by Carollia perspicillata (Phyllostomidae), a mediumbodied fruit-eating bat that is considered a Piper specialist (BIZERRIL; RAW, 1997). The shorttailed fruit bat forages using different sensory abilities and by means of echolocation and vision it distinguishes variations on Piper fruit size and morphology (THIES et al., 1998). Fruit smell is used as an imprecise cue to fruit location by bats
PIRES, L. P.; DEL-CLARO, K.; UIEDA, W;

(KORINE; KALKO, 2005). In PS, $P$. arboreum fruits did not exhibit evident differences in other morphological traits such as color, shape or accessibility, so it is reasonable to assume that if there is any preference based on fruit characters it would be on fruit size. The term 'fruit' was used in its ecological and functional rather than in its botanical meaning, since $P$. arboreum has actually infructescences. Nonetheless, bat choice is based on the whole infructescence. Moreover, $P$. arboreum fruits grow mainly in length, so it is referred as 'size' from hereafter.

\section{Methods}

To assess if fruit size varied in $P$. arboreum population, 14 trees (about $2 \mathrm{~m}$ high; similar number of stems and phenological state) were tagged with small, inconspicuous plastic bands. Individuals were selected so that a ten meters minimum distance was kept from one another. In each tagged plant, we labelled ten fruits of different sizes $(N=140)$. We also measured fruit size $(\mathrm{mm})$, weight $(\mathrm{mg})$ and mean seed size (15 seeds/fruit; $\mathrm{mm}$ ) of two unlabeled fruits taken from 14 nonexperimental neighboring plants. We used a $0.1 \mathrm{~mm}$ precision digital caliper and a $0.01 \mathrm{~g}$ precision weighing balance to record fruit measurements. Fruits from tagged plants were measured again every week until they were removed because they could have gotten bigger before reaching the maximum size. We recorded ripening time of each labeled fruit daily. Fruits of $P$. arboreum ripe late in the afternoon and are mostly consumed by bats on the same day (pers. obs., see also BIZERRIL; RAW, 1998). Therefore, average ripening time can be used as a synonym of fruit removal rate per plant.

To record fruit selection by bats, labeled fruits were visually searched on plants daily. When a tagged fruit was not found, the floor below plant perimeter ( $1 \mathrm{~m}$ radius) was inspected to avoid considering a fallen fruit (for example, by rain or wind) as a record of removal by bats. If a fruit was found, we checked for bat bite marks (small, evenly spaced perforations caused by teeth cusps). Therefore, a fruit was only recorded as having been chosen when: (a) it was neither found on plant nor on the floor; or (b) it was not found on plant, but it was on the floor within plant perimeter and presented conspicuous bat-bite marks.

In order to assess if fruits of $P$. arboreum were consumed by diurnal frugivores (e.g. birds, white-eared opossum), we visually checked plants twice a day (from $0730 \mathrm{~h}$ to $1000 \mathrm{~h}$; and from $1600 \mathrm{~h}$ to $1830 \mathrm{~h}$ ), during the first two weeks of study, accounting for $70 \mathrm{~h}$ of observation. From the 
Preferential consumption...

following week onwards, plants were checked only early in the morning, from August to October 2010 and from July to August 2011. To confirm $P$. arboreum consumption by bats, we conducted two hour night sessions observations $(28 \mathrm{~h})$ of all tagged plants. Finally, to verify $P$. arboreum consumption by $C$. perspicillata (and possibly other bat species), we performed captures using four mist nets $(9 \times 3$ meters, at ground height) opened near non-tagged fruiting individuals of $P$. arboreum for five hours after sunset. Captured bats were kept in cotton bags for $30 \mathrm{~min}$, after which they were released and the bag checked for feces and seeds.

\section{Data Analysis}

A Kolmogorov-Smirnov test was used to assess normality in the distribution of fruit sizes. The Mann-Whitney $U$ test was performed to compare the sizes of what was considered smaller $(<$ median fruit size) and bigger fruits ( $>$ median fruit size). Fruit size variation among individuals was assessed using the Kruskall-Wallis test and variation within individuals was assessed through the average coefficient of variation (CV). The Pearson's correlation test was used to analyze the relationship between fruit size and fruit width, weight and seed size. Additionally, in order to assess if there was indeed fruit preference by bats regarding to fruit size and that this preference was not simply a consequence of the removal of earlier matured fruits, we also tested (ANCOVA) if ripening time and fruit removal per plant was dependent of fruit size among plants. Finally, the analysis of
PIRES, L. P.; DEL-CLARO, K.; UIEDA, W;

relationship between fruit removal and fruit size was performed using a Spearman's correlation test. Statistical analyses were performed in Systat 10.2, following Zar (1999). Descriptive statistics are presented as mean \pm 1 standard deviation (SD), unless specified otherwise.

\section{RESULTS}

Four fruits were excluded from data analysis because they were infested by fungus during the study. Therefore, we analyzed 136 fruits. Fruit size of $P$. arboreum population in PS presented a nonnormal distribution $(P<0.001)$, and a mean size of $99.19 \pm 19.76 \mathrm{~mm}$ (Figure 1). The smallest fruit $(60.40 \mathrm{~mm})$ was only 44 percent of the size of the largest $(137.70 \mathrm{~mm} ; \mathrm{CV}=19.9 \%, N=136)$. Bigger fruits $(N=67)$ averaged $115.96 \pm 11.89 \mathrm{~mm}$ and the smaller $(N=69) 82.41 \pm 8.61 \mathrm{~mm}(U=4555.50 ; P$ $<0.001)$. Fruit size varied per plant $\left(H_{13}=14.50 ; P\right.$ $<0.001$ ) (Figure 2) and also within individuals (maximum $\mathrm{CV}=0.19 ;$ minimum $\mathrm{CV}=0.07$; average $\mathrm{CV}=0.12 \pm 0.03$ ).

Fruits weighed $2.20 \pm 1.14 \mathrm{~g}$ and seeds were $1.62 \pm 0.24 \mathrm{~mm}$ long. Fruit size was positively related to fruit weight and seed size $(N=28, r 0.83$ and 0.75 , respectively; $P<0.001$ ) (Figure 3 ).

A statistical significant difference was found in fruit ripening time (fruit removal rate) among plants $\left(F_{13,113}=3.67 ; P<0.001\right.$, ANCOVA $)$, although this difference was not related to mean fruit size per plant $\left(F_{1,113}=2.08 ; P=0.152\right.$, ANCOVA).

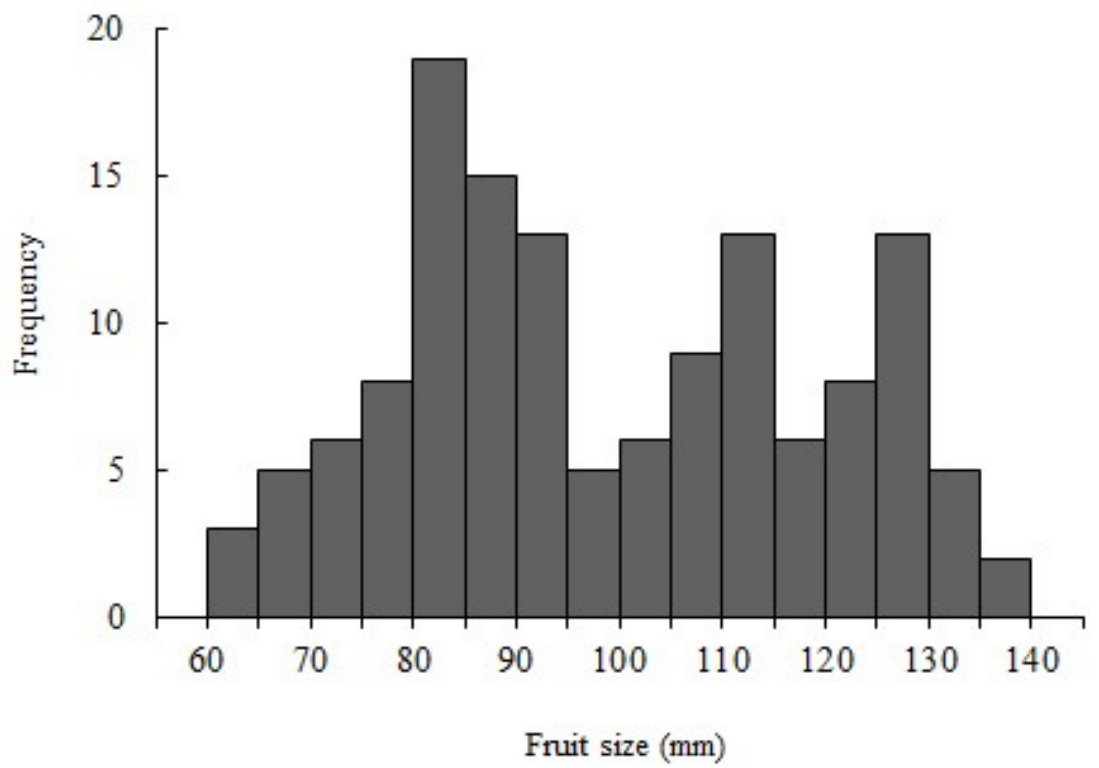

Figure 1. Frequency distribution of fruit size $(\mathrm{mm})$ in Piper arboreum population from Parque do Sabiá, municipality of Uberlândia, State of Minas Gerais, Southeastern Brazil. 


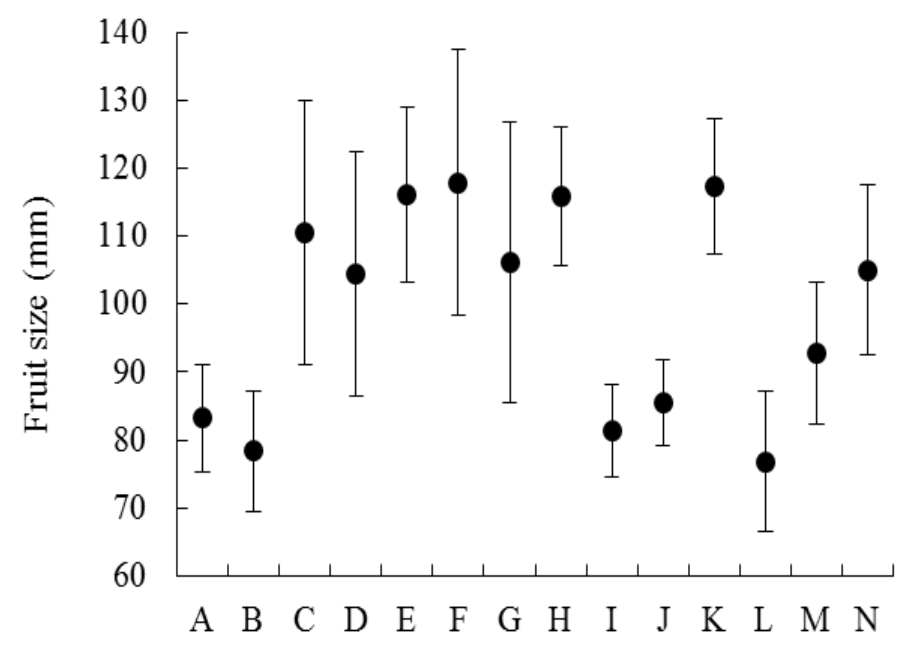

Plants

Figure 2. Mean fruit size (mm; circles) per individuals $(N=14)$ of Piper arboreum in Parque do Sabiá forest, municipality of Uberlândia, State of Minas Gerais, Southeastern Brazil. Whiskers represent standard deviation. Each plant is represented by an alphabetical letter. A) $83.20 \pm 7.88 \mathrm{~mm}$; B) $78.38 \pm 8.91$ $\mathrm{mm}$; C) $110.51 \pm 19,32 \mathrm{~mm}$; D) $104.43 \pm 18.09 \mathrm{~mm}$; E) $116.16 \pm 12.85 \mathrm{~mm}$; F) $117.90 \pm 19.55 \mathrm{~mm}$; G) $106.05 \pm 20.63 \mathrm{~mm}$; H) $115.85 \pm 10.25 \mathrm{~mm}$; I) $81.37 \pm 6.76 \mathrm{~mm}$; J) $85.40 \pm 6.31 \mathrm{~mm}$; L) 117.29 $\pm 10.04 \mathrm{~mm}$; M) $76.82 \pm 10.35 \mathrm{~mm}$; N) $92.86 \pm 10.45 \mathrm{~mm}$; O) $104.99 \pm 12.48 \mathrm{~mm}$.
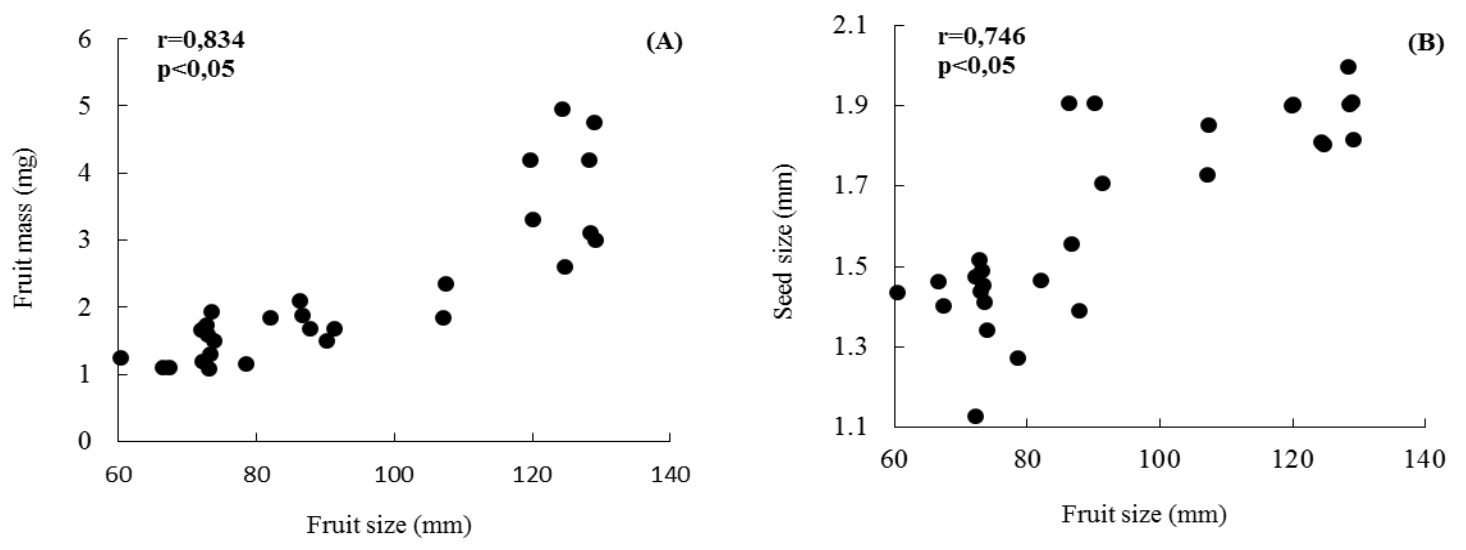

Figure 3. Pearson's correlations between fruit size and (A) fruit weight and (B) seed size of Piper arboreum in Parque do Sabiá forest, municipality of Uberlândia, State of Minas Gerais, Southeastern Brazil.

At PS, $128(91.40 \%)$ of the labeled fruits were considered to have been removed by bats. Mean fruit size available for selection decreased as fruits were removed from plants $\left(r_{\mathrm{s}}=-0.69 ; N=9 ; P\right.$ $<0.05$ ) (Figure 4). Variation in fruit removal explained about 50 percent $\left(R^{2}=0.48\right)$ of variation in the size of remaining fruits.

Four individuals of Carollia perspicillata were captured. From these, four fecal samples were obtained, of which three contained seeds, exclusively from $P$. arboreum. Four other phytophagous bat species - Artibeus lituratus (Olfers 1818), A. planirostris (Spix 1823),
Glossophaga soricina (Pallas 1766) and Platyrrhinus lineatus (E. Geoffroy 1810) - captured in the same study site (from which we obtained 19 fecal samples) and kept under the same conditions were not observed or recorded consuming fruits of $P$. arboreum. Moreover, no diurnal consumption of fruits of $P$. arboreum was observed, and the only nocturnal frugivore spotted approaching and consuming the fruits was the short-tailed fruit bat $C$. perspicillata. Bats always approached the fruitbearing plants more than once before removing the whole fruit in flight and never landed on plant to feed. 


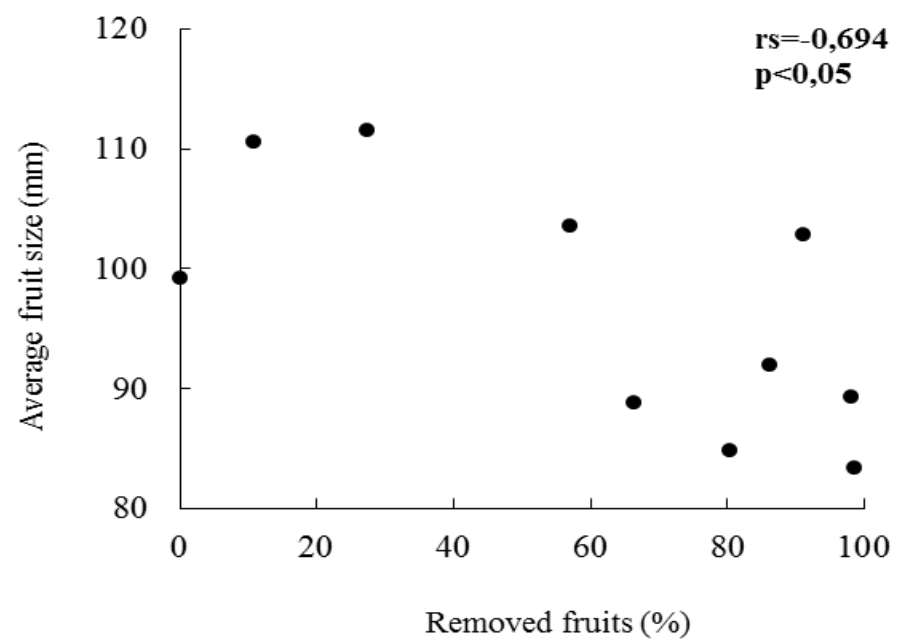

Figure 4. Spearman's correlation between proportion of fruits removed from plants (\%) and average size (mm) of remaining fruits in Piper arboreum individuals per week.

\section{DISCUSSION}

Our findings support the hypothesis of preferential consumption of larger fruits of Piper arboreum by Carollia perspicillata and also suggest that feeding behavior and plant phenological strategies are important in explaining fruit consumption and seed dispersal.

A specific fruit trait must vary among individuals within a population in order to allow frugivores to choose upon it (GAUTIER-HION et al., 1985). Fruit size varied among and within individuals of $P$. arboreum from PS, thus allowing bats to choose fruits in population and in individual levels (among plants and within an individual parental tree, respectively). The hierarchy of foraging decisions is important to understand plantfrugivore interactions (SALLABANKS, 1993).

Body size may limit the set of resources frugivores are able to consume, mainly because small-bodied animals would not be able to remove or handle large and/or heavy fruits efficiently without more sophisticated behavioral repertory (MARTIN, 1985, MUSCARELLA; FLEMING, 2008). In the present study, bigger fruits of $P$. arboreum did not restrict consumption by $C$. perspicillata, since these bats consumed both small and large fruits. Bizerril and Raw (1998) did not observe fruit removal by $C$. perspicillata as we did, but rather the consumption of fruits on the plant. This difference in fruit consumption behavior may be due to the much heavier and larger fruits reported in the previous study ( $9.4 \mathrm{~g} 169 \mathrm{~mm}$, respectively). Bats may need to use different behavioral strategies when foraging on different fruit traits (DUMONT, 1999), even if it is on the same plant species, and so it is reasonable to expect behavioral adjustments regarding the consumption of fruits differing in size (MOERMOND; DENSLOW, 1983).

Fruits of $P$. arboreum were systematically consumed by $C$. perspicillata, as bigger fruits were removed sooner than smaller ones, which corroborated our expectations. The preference for larger fruits may be explained by a cost-benefit relationship, as larger fruits hold more pulp than smaller ones and, consequently, more available energy (WENDELN et al., 2000). P. arboreum fruits are low quality resources, with many small seeds (BIZERRIL; RAW, 1997). Thus, foraging on bigger fruits may be the most energetically profitable strategy adopted by $C$. perspicillata, since it would attend its energetic requirements with fewer visits to fruiting plants, while reducing foraging time and predation risks (NUNES et al., 2007).

Despite the observed preference of bats for larger fruits, a considerable percentage ( $c a .50 \%)$ of fruit removal was not explained by bat choice. This is due to the fact that smaller fruits were also consumed during foraging activity. This result implies that other factors may limit fruit choice by bats (FLEMING et al. 1993, CARLO; MORALES, 2008, PIZO; ALMEIDA-NETO, 2009). Some of these factors are variation in nutritional quality, plant structure, crop size and distance among fruiting individuals (FOSTER, 1990, WENDELN et al., 2000, CARLO; MORALES, 2008). Additionally, results showed that $P$. arboreum reproductive strategy is one of these factors. In the study site, $P$. arboreum was basically a "steady state" plant (sensu GENTRY, 1974) regarding its fruiting pattern, which means that some individuals ripened only a few fruits late in the afternoon, asynchronously and independently of fruit size. This 
Preferential consumption...

pattern is similar to those described in the studies of Bizerril and Raw (1998) and Thies and Kalko (2004) for the same plant species. Hence, fruit availability was restricted per night, limiting bat choice to ripened fruits.

However, if larger fruits are more attractive to $C$. perspicillata, why does $P$. arboreum spend energy on the production of less preferred fruits and also restrict fruit availability? This could be explained by the presence of other frugivores that choose fruits of $P$. arboreum differently, but it could also be approached in terms of mutualism evolution. Plant-frugivore interactions are mutualistic associations (BASCOMPTE; JORDANO, 2007). Nevertheless, mutualisms are mutual exploitation interactions in which there are costs involved in their maintenance (BRONSTEIN, 2012). The amount of energy that plants allocate to produce larger fruits is greater than that allocated to smaller ones (HOWE; VANDE KERCKHOVE, 1981). Thus, $P$. arboreum can reduce mutualism costs and maintain the benefits of seed dispersal by constraining larger fruit availability, coercing bats to remove also the smaller fruits. Limitation in fruit availability by plants has also been investigated in previous studies (e.g. ORTIZ-PULIDO; RICOGRAY, 2000).

Interactions with frugivores have certainly played an important role in the diversification of plant structures (TIFFNEY, 2004). However, in order to clearly elucidate the coevolutionary patterns of plant-frugivore interactions, we suggest that studies should take into account not only the role of frugivore behavior in shaping plant and fruit diversity, but also plant characteristics, such as
PIRES, L. P.; DEL-CLARO, K.; UIEDA, W;

phenology, that constrain frugivore activity and, thus, selective pressure upon fruit traits.

\section{CONCLUSION}

Carollia perspicillata chose fruits of Piper arboreum on a size-based preference in a tropical dry forest fragment from Southeast Brazil. However, this behavior was strongly influenced by plant phenology, since fruit availability was constrained each night. Although plant-frugivore interactions have long been studied in community ecology, there is no consensus on what are the determinants of fruit choice, if there is any. Further insight is needed on this subject in order to understand the ecological and evolutionary implications of fruit choice.

\section{ACKNOWLEDGMENTS}

The authors would like to thank Natália O. Leiner, Wesley R. Silva and Marco A. Pizo for helpful comments on earlier versions of the manuscript; Giâncarlo A. Ferreira, Diego P. C. Teodoro, Vanessa F. Gonçalves, Carolina M. Freitas, Alexandre O. Rezende and Adriano M. Silva for inestimable help during field-work; the staff of Parque do Sabiá Zoo; Coordenação de Aperfeiçoamento de Pessoal de Nível Superior (CAPES) and Programa de Pós-Graduação em Ecologia e Conservação dos Recursos Naturais for financial support; Conselho Nacional de Desenvolvimento Científico e Tecnológico (301248/2009-5 and 473055/2012-0) for research grants.

RESUMO: Os frugívoros utilizam as características morfológicas dos frutos tais como tamanho, dureza, forma, cor e cheiro, como pistas para avaliar o custo-benefício da atividade de forrageio. O tamanho dos frutos é uma característica importante que influencia o comportamento alimentar dos frugívoros, já que existe uma correlação funcional entre tamanho do fruto e o do tamanho do frugívoro. Por isso, a seleção do fruto a partir do seu tamanho é um elemento fundamental para a compreensão das interações frugívoro-planta e da dispersão de sementes. Neste sentido, nós testamos a hipótese de consumo preferencial de frutos maiores de Piper arboreum pelo morcego Carollia perspicillata em uma floresta tropical brasileira. Os resultados mostraram ampla variação no tamanho do fruto entre e dentro das plantas parentais. Também houve diferença significativa no tempo de maturação dos frutos entre as plantas, o qual não esteve relacionado com o tamanho do fruto. O tamanho médio dos frutos restantes na planta após a remoção pelos morcegos decresceu, o que indicou o consumo preferencial dos frutos maiores. Por outro lado, a fenologia da planta restringiu o consumo destes frutos. Um número pequeno de frutos maduros esteve disponível para o consumo por noite, independentemente de seu tamanho, o que provavelmente limitou a escolha dos morcegos, obrigando-os a se alimentarem dos frutos menores conforme a disponibilidade dos maiores reduziu-se. Os resultados sugerem que a preferência dos morcegos pelo tamanho dos frutos é mediada pelas estratégias fenológicas das plantas.

PALAVRAS-CHAVE: Escolha do fruto. Frugivoria. Dispersão de sementes. Síndromes. Brasil. 


\section{REFERENCES}

BASCOMPTE, J.; JORDANO, P. Plant-animal mutualistic networks: the architecture of biodiversity. Annual Review of Ecology, Evolution and Systematics, Palo Alto, v. 38, p. 567-569, 2007.

http://dx.doi.org/10.1146/annurev.ecolsys.38.091206.095818

BIZERRIL M. X. A.; RAW, A. Feeding specialization of two species of bats and the fruit quality of Piper arboreum in a Central Brazilian gallery forest. Revista de Biologia Tropical, San José, v. 45, p. 913-918, 1997.

BIZERRIL, M. X. A.; RAW, A. Feeding behavior of bats and the dispersal of Piper arboreum seeds in Brazil. Journal of Tropical Ecology, Oxford, v. 14, p. 109-114, 1998. http://dx.doi.org/10.1017/S0266467498000108

BRONSTEIN, J. Antagonismos e mutualismos: interações entre plantas e animais. In: DEL-CLARO, K.; TOREZAN-SILINGARDI, H. M. (Org.). Ecologia das interações plantas-animais: uma abordagem ecológico evolutiva. Rio de Janeiro: Technical Books Editora, 2012. p. 293-304.

CAMARGO, M. G. G.; CAZETTA, E.; SCHAEFER, H. M.; MORELlATO, L. P. C. Fruit color and contrast in seasonal habitats - a case study from a cerrado savanna. Oikos, Munich, v. 122, p. 1335-1342, 2013. http://dx.doi.org/10.1111/j.1600-0706.2013.00328.x

CARLO, T. A.; MORALES, J. M. Inequalities in fruit-removal and seed dispersal: consequences of bird behaviour, neighbourhood density and landscape aggregation. Journal of Ecology, Oxford, v. 96, p. 609-618, 2008. http://dx.doi.org/10.1111/j.1365-2745.2008.01379.x

DEL-CLARO, Kleber; TOREZAN-SILINGARDI, Helena Maura. Ecologia das interações plantas-animais: uma abordagem ecológico evolutiva. Rio de Janeiro: Technical Books Editora, 2012.

DUMONT, E. R. The effect of food hardness on feeding behaviour in frugivorous bats (Phyllostomidae): an experimental study. Journal of Zoology, London, v. 248, p. 219-229, 1999. http://dx.doi.org/10.1111/j.14697998.1999.tb01198.x

DUMONT, E. R.; IRVINE, A. K. Old world bat fruits: diversity and implications for pteropodid ecology. Bat Research News, Bloomington, v. 39: p. 166, 1998.

FLEMING, T. H. The relationship between body size, diet, and habitat use in frugivorous bats, genus Carollia (Phyllostomidae). Journal of Mammalogy, Lawrence, v. 74: 493-501, 1991.

http://dx.doi.org/10.2307/1382132

FLEMING, T. H.; VENABLE, D. L.; HERRERA, L. G. M. Opportunism vs. specialization: the evolution of dispersal strategies in fleshy-fruited plants. Plant Ecology, Perth, v. 107-108, p. 107-120, 1993.

FLÖRCHINGER, M.; BRAUN, J.; BÖHNING-GAESE, K.; SCHAEFER, H. Fruit size, crop mass, and plant height explain differential fruit choice of primates and birds. Oecologia, Munich, v. 164, p. 151-161, 2010. http://dx.doi.org/10.1007/s00442-010-1655-8

FOSTER, M. S. Factors influencing bird foraging preferences among conspecific fruit trees. The Condor, Oklahoma, v. 92, p. 844-854, 1990. http://dx.doi.org/10.2307/1368720

FUENTES, M. Diets of fruit-eating birds: what are the causes of interspecific differences? Oecologia, Munich, v. 97, p. 134-142, 1994. http://dx.doi.org/10.1007/BF00317917 
GAUTIER-HION, A.; DUPLANTIER, J. M.; QURIS, R.; FEER, F.; SOURD, C.; DECOUX, J. P.; DUBOST, G.; EMMONS, L.; ERARD, C.; HECKETSWEILER, P.; MOUNGAZI, A.; ROUSSILHON, C.; THIOLLAY, J. M. Fruit characters as a basis of fruit choice and seed dispersal in a tropical forest vertebrate community. Oecologia, Munich, v. 65, p. 324-337, 1985. http://dx.doi.org/10.1007/BF00378906

GENTRY, A. H. Coevolutionary patterns in central american Bignoniaceae. Annals of the Missouri Botanical Garden, Saint Louis, v. 69, p. 728-759, 1974.

GUILHERME, F. A. G.; NAKAJIMA, J. N.; LIMA, C. A. P.; VANINI, A. Fitofisionomias e a flora lenhosa nativa do Parque do Sabiá, Uberlândia, MG. Daphne, Belo Horizonte, v. 8, p. 17-30, 1998.

HERRERA, C. M. Seed dispersal by vertebrates. In: HERRERA, C. M; PELLMYR, O. (Ed.) Plant-animal interactions, an evolutionary approach. Oxford: Blackwell Science, 2002. p. 185-208.

HOWE, H. F.; VANDE-KERCKHOVE, G. A. Removal of wild nutmeg (Virola surinamensis) crops by birds. Ecology, New York, v. 62, p. 1093-1106, 1981.

JANSON, C. H. Adaptation of fruit morphology to dispersal agents in a Neotropical forest. Science, New Jersey, v. 219, p. 187-189, 1983.

JORDANO, P. Frugivore-mediated selection on fruit and seed size: birds and St. Lucie's cherry, Prunnus mahaleb. Ecology, New York, v. 76, p. 2627-2639, 1995.

KORINE, C.; KALKO, E. K. V. Fruit detection and discrimination by small fruit-eating bats (Phyllostomidae): echolocation call design and olfaction. Behavioral Ecology and Sociobiology, New York, v. 59, p. 12-23, 2005. http://dx.doi.org/10.1007/s00265-005-0003-1

LOMÁSCOLO, S. B.; LEVEY, D. J.; KIMBALL, R. T.; BOLKER, B. M.; ALBORN, H. T. Dispersers shape fruit diversity in Ficus (Moraceae). Proceedings of the National Academy of Sciences, Washington, v. 107, p. 14668-14672, 2010.

LOMÁSCOLO, S. B.; SCHAEFER, H. M. Signal convergence in fruits: a result of selection by frugivores? Journal of Evolutionary Biology, Saint Andrews, v. 23, p. 614-624, 2010.

MARTIN, T. E. Resource selection by tropical frugivorous birds: integrating multiple interactions. Oecologia, Munich, v. 66, p. 563-573, 1985. http://dx.doi.org/10.1007/BF00379351

MELLO, M. A. R.; LEINER, N. O.; GUIMARÃES JR, P. R.; JORDANO, P. Size-based fruit selection of Calophyllum brasiliense (Clusiaceae) by bats of the genus Artibeus (Phyllostomidae) in a Restinga area, southeastern Brazil. Acta Chiropterologica, Brasília, v. 7, p. 165-188, 2005.

MOERMOND, T. C.; DENSLOW, J. S. Fruit choice in neotropical birds: effects of fruit type and accessibility on selectivity. Journal of Animal Ecology, London, v. 52, p. 407-420, 1983. http://dx.doi.org/10.2307/4562

MUSCARELLA, R.; FLEMING, T. H. The role of frugivorous bats in tropical forest succession. Biological Reviews, Cambridge, v. 82, p. 573-590, 2008. http://dx.doi.org/10.1111/j.1469-185X.2007.00026.x

NUNES, M. S.; CIFALI, A. P.; ESBÉRARD, C. E. L. Maiores figos atraem mais morcegos? Revista Brasileira de Zoologia, Curitiba, v. 9, p. 213-217, 2007.

ORTIZ-PULIDO, R.; RICO-GRAY, V. The effect of spatio-temporal variation in understanding the fruit crop size hypothesis. Oikos, Munich, v. 91, p. 523-527, 2000. http://dx.doi.org/10.1034/j.1600-0706.2000.910314.x 
PIZO, M. A.; ALMEIDA-NETO, M. Determinants of fruit removal in Geonoma pauciflora, an understory palm of neotropical forests. Ecological Research, Tokyo, v. 24, p. 1179-1186, 2009.

http://dx.doi.org/10.1007/s11284-009-0599-0

PYKE, G. H. Optimal foraging theory: a critical review. Annual Review of Ecology and Systematics, Palo Alto, v. 15, p. 523-575, 1984. http://dx.doi.org/10.1146/annurev.es.15.110184.002515

SALLABANKS, R. Hierarchical Mechanisms of fruit selection by an avian frugivore. Ecology, New York, v. 74, p. 1326-1336, 1993.

STANLEY, M.; SMALLWOOD, E.; LILL, A. The response of captive silvereys (Zospterops lateralis) to the colour and size of fruit. Australian Journal of Zoology, Melbourne, v. 50, p. 205-213, 2002.

http://dx.doi.org/10.1071/ZO01035

THIES, W.; KALKO, E. K. V. Phenology of neotropical pepper plants (Piperaceae) and their association with their main dispersers, two short-tailed fruit bats, Carollia perspicillata and C. castanea (Phyllostomidae).

Oikos, Munich, v. 104, p. 362-376, 2004. http://dx.doi.org/10.1111/j.0030-1299.2004.12747.x

THIES, W.; KALKO, E. K. V.; SCHNITZLER, H. U. The roles of echolocation and olfaction in two neotropical fruit-eating bats, Carollia perspicillata and C. castanea, feeding on Piper. Behavioral Ecology and Sociobiology, New York, v. 42, p. 397-409, 1998. http://dx.doi.org/10.1007/s002650050454

TIFFNEY, B. H. Vertebrate dispersal of seed plants through time. Annual Review of Ecology and Systematics, Palo Alto, v. 35, p. 1-29, 2004.

VAN DER PIJL, L. Principles of dispersal in higher plants. Berlin: Springer-Verlag, 2004.

WENDELN, M. C.; RUNKLE, J. R.; KALKO, E. K. V. Nutritional values of 14 fig species and bat feeding preferences in Panama. Biotropica, East Anglia, v. 32, p. 489-501, 2000.

WHEELWRIGHT, N. T. Fruit size, gape width, and the diets of fruit-eating birds. Ecology, New York, v. 66, p. $808-818,1985$.

ZAR, J. H. Bioestatistical analysis. New Jersey: Prentice-Hall, 1999. 